\title{
Self-Identity of Borderland
}

Self-Proclaimed Donetsk People's Republic: Emerging Society

\author{
Yelena A. Babkina
}

\begin{abstract}
This paper is based on the results of field research conducted by the author in Donbass in 2015-2017 and studies the media space and everyday communication in social networks and face-to-face conversations inside the self-proclaimed Donetsk People's Republic. We studied various types of internal discourse, the use of recognizable symbols and everyday practices to see whether the new political reality matches certain social reality and whether political borders have any correlation to social borders. Political separation of this part of Ukraine and mobilization by the local political forces of local identity symbols require people to reevaluate their views concerning the community they live in and its borders associated with a certain territory, the state system, ideology, and social connections. People are developing new self-identity approaches which are tested and implemented in emerging new contexts and related discourses. This work analyzes narratives related to the new socio-political (self-)identity in the process of its evolvement and alludes to a wide range of studies focusing on identity as a category of practice, social construction of borders, inclusion/ exclusion mechanisms, and collective memory.
\end{abstract}

Key words: Local identity, local communities, post-Soviet state, Donetsk Republic, collective memory

Yelena A. Babkina is an anthropologist and a researcher at the Research University-Higher School of Economics in St. Petersburg.

SPIN РИНЦ: 5036-9961

ORCID: http://orcid.org/0000-0001-6182-3666

ResearcherID: R-3968-2016

ebabkina@hse.ru

DOI: $10.31278 / 1810-6374-2018-16-2-106-120$ 
This project involves knowledge from several overlapping areas of cultural anthropology. The first of them studies the formation

and functioning of post-Soviet identities, consolidation of local communities in the post-Soviet space, their self-identity with regard to the state, system crises during economic and political transformations, power hierarchies, and official ideologies. We believe it important to mention the authors whose works without any doubt provided the methodological basis for our study: Caroline Humphrey (2010) and Serguei Oushakine (2009). The second key concept used in our work was the notion of social life of the state (Ssorin-Chaikov, 2003) which puts the research focus on social statuses, roles, remarks made in everyday interactions, as well as routine practices and references to local historical narratives in conversations with a view to studying the attitude of local communities towards the state and statehood. This approach complements the study of symbolic policy (Malinova, 2015; Miller, 2012) which is carried out by the authorities and absorbed and transformed, one way or another, by the communities through official events or everyday life. While studying the circulation of political symbols, which become overgrown with numerous references and mold alternative texts and discourses that exist in parallel to the official ones, we also study collective memory concerning recent developments (since the early 2014) and some other events in Soviet and post-Soviet history as well as the emergence of a certain memorial culture (Assman, 2014) within a community, which we define as the cornerstone of local identity.

Political developments in Donbass induce imminent changes in people's minds. The purpose of this work is to study how after years of hostilities the situation has necessitated a new self-identity that helps the average person adjust to new social contexts. Within these new contexts people have to master new social roles. They find a means of talking about the realities and personal experiences and learn how to use them as a sign of being included in or excluded from the community, or as a social resource. Each of these social contexts has its own communicative structure (or structures). Their combination creates a special communicative culture or communicative space, 
which incorporates all residents of a given territory. This is where changes in the community's self-perception manifest themselves.

The self-identity of a Donetsk People's Republic (DPR) resident should be understood wider than just public expression of loyalty to the self-proclaimed state or the ideological doctrines it professes. In a number of cases it is not confined to reciting well-established clichés attributed to the "Donbass identity." It is important to remember that this self-identity functions as a social practice and relies on personal experience and the experience of the whole community obtained over the past few years. It goes without saying that it is heterogenous and dynamic. There certainly exist some "wrinkles" and discrepancies, some of which are quite obvious to society (for instance, some people's lack of firsthand experience of "war going on next door", which we will discuss later), while others become noticeable only after thorough analysis.

The practices, rhetoric and easily recognizable symbols of the new authorities and new political culture that have developed under the new political and economic system perform two functions. They work as a means of self-representation to an external onlooker (the latter's role is often played by an abstract "state" as a safeguard and a resource of social justice), as well as a way of achieving horizontal solidarity of the community within new borders and in new conditions. In either case we certainly see spontaneously emerging contexts for a new selfidentity and the establishment of corresponding rituals and ritualized practices.

Both everyday and ritual-related contexts are connected with (1) the knowledge and adoption of the symbols of the new government, (2) the experience of living within the borders that emerged on the map of the former Donetsk Region, (3) the existence of local warrelated stories and means of discussing wartime realities that do not coincide with the discourse of Russian and Ukrainian propaganda. In everyday life DPR residents need all this at least for getting some useful information from daily newspapers and for understanding their neighbors. This is a result of the social transformation that has shaped the community within the self-proclaimed republic. It is connected 
with the system of symbols, the language, the social order, and the high degree of dependence on the informal economy. Speaking in modern ethnographic terms, a number of practices and social categories within the DPR in 2014-2015 acquired emic (in other words, clear to locals) interpretations, and also a set of etic ones ("border," "war," "military," "state")—analytical, extra-contextual, fraught with the risk of generalizations and excessive politicization. In precisely the same fashion new phenomena in the life of society or, as it happened to the Ukrainian language in schools, the preservation of the previous state of things acquire emic explanations, often relying on easily recognizable texts from the local mass media, rumors circulating in everyday conversations, or in Internet folklore.

Let us take a look at the most important ideas, terms, and social phenomena around which the self-identity of a DPR resident is centered, and their contexts in the media space and in everyday talk. These include extensive debates on the state and state power (new, old and Soviet), the rules of crossing the line of contact between the DPR and Ukraine, and also everyday and ritualistic symbolism of the current military standoff.

\section{THE STATE}

The state and state power are the focal points of post-Soviet public debates regardless of their format, be it Soviet nostalgia, public interpretations of history or social affairs. However, in a situation where the political regime is being changed, government monopoly on violence disintegrates and hostilities are underway the theme of statehood is particularly important for society's self-representation. This concerns, above all, the "retreat" of the state (Ukrainian) and, secondly, the emergence of alternative symbols of governmenteverything that concerns the self-proclaimed state.

In the former case, people achieve self-representation and express individual and collective memory by describing the inactivity/ indifference of the authorities or a vacuum of power at different levels in 2014-2015, when only the Ukrainian authorities had the symbolic and administrative resource of the state. The-government-has- 
abandoned-us rhetoric was quite common in the media at that time and still is in people's reminiscences up to date. Among the important topics of such stories are the lack of communication between the authorities and residents of the conflict-ridden territories during military operations (for instance, the absence of official instructions regarding the establishment of martial law that suspends the operation of some organizations, etc.), a news blackout, and a number of other restrictions (on the freedom of movement and the use of bank cards) that forced people to look for ways of survival. There are also situations in which the authorities-old or new-assert themselves solely by using violence, which performs a symbolic function or is aimed at overcoming non-systemic violence ("lawlessness").

With the passage of time the "power vacuum" discourse becomes relevant for philistine description of social affairs inside the unrecognized state among both the supporters of the Donetsk People's Republic and those whose political views remain inexplicit. Too wide is the gap between expectations from the new authorities vowing to establish new statehood and personal efforts to normalize and provide social guarantees. As a rule, such expectations stem from the imaginary Soviet-style practices when the "bosses" (politicians) and "foremen" (industrialists) make a contract for the exchange of labor and resources, including not just material values, but also tolerance towards the shadow economy and lack of complete political loyalty.

In the latter case we identify a number of means (texts, rituals, practices, and artifacts) which the DPR authorities that position themselves as a new state use to express the identity of the community. These include allusions to the easily recognizable Soviet symbols and direct references to the Soviet past (and practices of interaction with it) to describe everything DPR-related as non-Ukrainian, as well as formalization of symbolic swaps between the state and the individual (utility bill payments in exchange for social benefits or re-registration of businesses in the DPR in exchange for the placement of military draft offices' adds in shop windows). As a result, there appears a set of relevant forms of interaction between ordinary people and the new authorities, reflecting the former's expectations the latter are to 
match (for instance, struggle against black market profiteering) and the acceptance of the new political realities (the flag and the DPR's own foreign currency exchange rate in 2014-2015), as well as events having a high semiotic status (dialogs with DPR leader Alexander Zakharchenko in live television broadcasts or the laying of flowers at Lenin's monuments), and official rituals evoking memories of the collective past, both Soviet and recent, where military and militarized parades hold a prominent place. Due to its economic weakness the DPR's policy of symbols becomes the sole available means of restoring the presence of the state in different contexts of social life after the period when the understanding of who has the power was confined to the military presence of this or that side.

Alongside this the authorities of the self-proclaimed republic, the local media and the public at large are quite close in how they view the debt of the state (Ukraine) to ordinary people. Any reference to material (social benefits and loans) and symbolic assets (documents, higher education) of the Ukrainian state is regarded as a creditordebtor relationship. In this case the DPR public's understanding of its intangible asset is confined to the idea that "Our due to the state has been paid in full" both from historical perspective (i.e. in the days of Soviet Ukraine's industrial boom and prosperity, which is still written about by local authors and recalled on benches in public gardens and in the queues at border checkpoints) and from the current point of view-by living through the hardships of military hostilities and "lawlessness." People and the local media slam the economic restrictions the Ukrainian government has maintained against the territories beyond its control since 2014 as "a blockade" (a clear allusion to the World War II siege of Leningrad). They are still discussed at border checkpoints on the line of contact between the warring sides and in complaints addressed to external arbiters (OSCE monitors, journalists and casual fellow travelers from other countries).

\section{BORDERS}

Modern anthropological theories pay special attention to borders and trans-border exchanges such as migration flows and economic and 
cultural ties. It is borders and the related border-crossing practices that serve as a context for the emergence and existence of new types of self-identity and identification of others. Moreover, just as in the case of DPR residents' self-identity, the border itself, to be more precise, its presence in everyday life is a self-identity resource. In everyday perception, propagated by local media, border issues are used for describing asymmetrical, in other words, unfair relations between the state (Ukraine) and some of its residents (who are at the same time residents of the DPR). These relations are the cornerstone of society's self-identity.

There are also some other aspects of symbolic and practical perception of the border. Everyday life itself appears to be a borderline between "this" and "that" territory. It has more than just a cultural meaning, although people tend to draw foreigners' attention to changes in the content of billboards and other messages manifesting the cultural and political context. The very existence of border-crossing rules is far more important, for it is closely linked with learning the code of behavior and communication with fellow travelers, border infrastructures of the two conflicting parties and, lastly, with people "in the other territory." Shuttle trips "there and back" are often made for getting social allowances or buying goods that are in short supply, less expensive or more familiar in terms of quality and appearance (sometimes "Ukrainian" goods enjoy a higher symbolic status and/or bear special quality marks in contrast to goods which are produced in the disputed territory and which are reputed to be of "inferior" quality). Also, people move back and forth because they work, study or get medical help in the other territory. All this creates hypersemiotic spaces of self-identity and solidarity within society, which manifests itself in the emergence of networks of trust and mutual assistance, having various degrees of stability from spontaneous to nearly permanent.

In this sense the self-identity of DPR residents serves as a "cultural resource." U.S. anthropologist Olga Shevchenko uses this term to determine the nature of everyday relations in the post-Soviet culture of total crisis. It incorporates a system of personal ties and survival 
lifehacks as well as a permanent feeling of collapse (social and governmental-this takes us back to the theme of the state), which are conducive to extensive use of informal economic practices coupled with external loyalty towards the political regimes. For instance, before the DPR had introduced the official exchange rate of foreign currencies (three rubles for one hryvnia) and the free circulation of both currencies in the territories of the self-proclaimed republics (i.e. before September 2016), there existed a so-called official "republican rate" (two rubles to one). Accordingly, there existed a wide practice of informal cash exchanges at the "normal" or bargain exchange rate (three rubles to one or higher) as a sign of loyalty to the DPR authorities. The DPR's government campaigns for improving social insurance and tightening the grip on the informal economy draw a certain response (some comments are quite typical in the post-Soviet space, for instance "a crackdown on profiteers"). But the awareness that the official and social (or socioeconomic) orders do not quite match is a far more important structural feature of the community of residents in the self-proclaimed republic.

A self-proclaimed state is important as long as it takes care of education, health care services and urban infrastructures (quite often witnesses sharing impressions of life in the DPR express surprise over clean streets and tidy public gardens, the effective performance of utility services when hostilities flare up and also policies in the field of education, youth sports and leisure) and the customary memorial practices (in particular, the preservation of the urban environment of the late Soviet and early post-Soviet period with the inherent place names and festive activities, in contrast to modern Ukraine). However, maintenance of social order and normalization of life amid hostilities go beyond that state's sphere of activity and imply-in this sense, the DPR stands next to many post-Soviet countries-far greater significance of migration networks and the shadow economy. Generally speaking, people attach great importance to their own (as opposed to governmental) initiatives to restore life to "normal" by running a business, doing creative work, organizing sport events, providing charitable help or monetizing individual hobbies. 
The longing for peace in everyday life manifests itself in symbolic actions to remind the authorities of pre-war realities. This explains the origin of "No Guns Allowed" signs or quite implicit rules of conduct for military personnel in the public space identical to those civilians are obliged to abide by. Although manifestations of government paternalism in the DPR and pro-Soviet rhetoric are much in sight and generally welcome, there is no return to Soviet ideas of interaction between the individual and the state. With the new authorities in office and possessing such a symbolic resource as nostalgia for the 1970s, the DPR people by no means become "grown-up children"-a term coined by Ilya Kalinin- "as liberal critics described Soviet people during perestroika and turned out to be very close to the truth." It is the other way round. The DPR people are actively creating social networks cemented by economic interest and crisis-induced solidarity. These networks often involve people residing in Ukraine. Day-to-day contacts in many cases are not disrupted. People just try to avoid discussing sensitive themes and issues.

\section{WAR}

Lastly, the common experience of "this war" is the most important resource of group solidarity and self-identity of the DPR's people. It underlies day-to-day life, its economic and political volatility, the constant question whether all members of a family should migrate or only some of its generations, and the preservation of individual and collective memory of events. The latter includes typical stories about war realities in everyday talk and the establishment of memorial sites and commemorative practices in real life and in cyberspace.

Inside the community the notion of 'war' has an emic interpretation (as it was already stated above), that is, it relies on local contexts. Local people can understand war as the current conflict in its entirety, starting from the spring of 2014, when the first clashes between the supporters of the Donetsk Republic and the Ukrainian army occurred in Slavyansk and Kramatorsk, or from May 26 (the day when hostilities around the Donetsk airport began). The latter date is referred to in the media and the DPR's social networks as the day when the war broke 
out. Each anniversary triggers spontaneous flash-mobs in the social networks, with contributors uploading their own recollections of events (the political component of rhetoric as a rule is focused on the Ukrainian army's use of heavy lethal weapons without warning and control of the situation) and other commemorative texts. In everyday talk people may use the term 'war' in relation to the period or periods of increased hostilities, including heavy shelling of urban areas in the summer of 2014 and January-February of 2015 (in some places, for instance, in Gorlovka one may hear such phrases as "the first war" and "the second war"). This is the reason for certain chronological discrepancies and "gaps" in the collective memory that may look strange to onlookers. Certain events important to some people as key moments of the war may be little known or totally unknown in other cities or even districts of the same city.

Local people point to a similar discrepancy in the collective perception of war. For some people "war" is a past event ("I always say that everything is calm in my backyard"), while for others it is part of "the present" and current experiences they have to live through day by day simply because they happen to be close to the areas of hostilities and irreparable human and material losses. In some situations this discrepancy in perception may acquire moral aspects: In one interview a university student criticizes her teacher for refusing to be more gentle during an exam with a student who lives close to the line of contact between the warring sides, because "there is no war going on at the moment," while another informant is angry about her colleague for a negative attitude (in her opinion) towards those "who have forgotten the war and do not wish to recall it," because they live in calmer areas.

On the whole, everyday talk often focuses on contrasts between the "center" (central parts of Donetsk) and the "periphery" (outlying districts). The reason is not just the distance from the frontline, but also the retained pre-war economic and cultural lifestyles. The latter is true only with a number of reservations, though. In their comments on the current economic realities local people display unanimity whenever they recall prewar prices, goods, jobs, and prospects. Before the war prices were lower, goods and services were of better quality 
and more affordable. As for the labor market and future prospects, there are a number, albeit small, of positive personal experiences, as a rule, due to reorientation to the Russian market or one's own private initiative in business.

War shapes the community of DPR residents in the symbolic space to a greater extent than everyday personal experiences. It is noteworthy that the notion of 'war' began to be used in common talk and local media in 2014. It emerged as a counter-term to Kiev's official cliché "Anti-Terrorist Operation (ATO)," which was in use until Ukraine recently officially declared it was a war against a foreign aggressor. Ideologically (and ideology may be present in everyday talk, too) the war in Donbass may be described as defensive, civil, hybrid or "modern." Ordinary people prefer to describe it as "undeclared." What they have in mind is the unfavorable information and social policies of the state and the tragedy of accidental civilian casualties. The events of 1992 in Transnistria are referred to similarly, while the phrase "innocent victims of an undeclared war" can be found in the captions to photographs from Bendery posted in the local media and on memorial signs in the DPR's cities placed by the district authorities.

Rituals performed at or around memorial sites and joint commemoration ceremonies are acknowledged methods of declaring the unity of imaginary communities. It is quite natural that war memorials are part of the DPR authorities' remembrance policy. Government rituals reconstruct memories and piece together local episodes into an integral narrative about the war and those killed in it in order to enhance the legitimacy of the political regime. This process began before concrete state structures were created in the selfproclaimed republic. It started with the installation of memorial signs honoring the "first victims" (personnel of the Berkut crack police unit killed or injured in Kiev in February 2014, Slavyansk's resident Ruben Avanesian, medical nurse Yulia from Kramatorsk, and Odessa residents killed in clashes on May 2, 2014) near the building of the regional administration in Donetsk (it was stormed and taken by the Donetsk Republic's defenders on April 7, 2014). This process culminated in the symbolic acts of inaugurating a monument to the killed DPR citizens 
and, separately, the Angels' Alley, a memorial dedicated to the killed children of the DPR (the middle of 2015). Civilian casualties are included in the history of the war at the local level, too. The Gorlovka administration has replaced the memorial sign commemorating the victims of the July 27, 2014 bombardment of the city with a war memorial for all local people killed in the hostilities, with their names carved in stone.

State interference changes not just the chronology of events, but the narrative as well-instead of "undeclared war" the stela bears the inscription "The Kiev junta's aggression."

All official rituals and related rhetoric take the perception of war as an event to a new level. From the very start of the confrontation the local media have been drawing parallels with the Great Patriotic War with the aim of legitimating DPR combatants. Since 2015 they have been taking an active part in customary Great Patriotic Warrelated commemorative practices and new ones invented in order to pool historic memory and recollections of recent events into one whole. "That" war and "this" war are treated as similar events in poetic works by local authors and in the rituals initiated by the republican authorities. With reliance on the ideology of at least part of the combatants, the narrative of the war as one undivided event, "which did not end in 1945," incorporates not only the struggle between the Soviet Army and the underground in Western Ukraine up to 1953, but also combat operations in Afghanistan, Tajikistan, Nagorno-Karabakh, Abkhazia, Transnistria, and former Yugoslavia. Veterans of those wars who have joined the DPR army appear at official events side by side with Great Patriotic War veterans, locals who joined the militias and eventually the DPR army, and civilians harmed in the ongoing conflict to emphasize the continuity of the series of standoffs in which the community of DPR residents is involved. Veterans of the Afghan War and other "internationalists" observe remembrance days attended by members of the media, public organizations, and schoolchidren.

Controversial "patriotism of local wars" in the post-Soviet space is partially blended into commemorative texts. There one finds civic duty rhetoric, criticism of politicians' arbitrariness and disregard for 
people's lives (as in a song by an Afghan War veteran and amateur song writer), and oblivion in the 1990. Both messages are consonant with the local people's attitude to war, which is often a combination of patriotic enthusiasm and the feeling of social injustice.

Alongside rituals the commemoration of military events is being built into everyday life as a ritualized practice. One of my informants has kept a photo diary of events since July 1, 2014 (the day when hostilities began in his area) to capture the war in everyday life. There are photographs of trenches in the streets, human bodies, a shell-shocked cat, and industrial plants continuing to work during bombardments. The link between the public and private parts of reminiscences can be seen in contributions uploaded to social networks and in publications featuring people's diaries and eyewitness accounts. One way or another, all of them are self-representations of separate individuals and the community as a whole in a territory separated by roadblocks and living through armed hostilities. By describing the daily wartime routine, the authors show how the DPR people are building their self-identity by learning news and actors and gaining emotional experience. Personal stories and published works describe acute sound sensitivity, put-on indifference, determination to follow customary peacetime habits during bombardments, the knowledge of what is to be done in certain dangerous circumstances, sources of the latest information about security in the city (such as Self-Defense groups in the social network VKontakte), location of remembrance sites, and the fundamental refusal to think about critical events ("I don't care who is shooting)."

From an outsider's point of view there are two poles. There are civilians with Ukrainian passports, who have happened to be on the territory ripped apart by an armed conflict and forced to survive in the new realities, and there are "DPR citizens," who have agreed to accept new leaders and new passports. But a close look at the practices and texts that I believe are the closest to the average person's daily discourse shows that neither option reflects all possible contexts in which DPR 
residents begin to share a common "We." There is enough evidence to say that starting from 2015 the self-identity of DPR people has been steadily gaining strength in the public space ("Are you going to stay long with us in the DPR?"- - line from a private letter sent in the summer of 2015) alongside state symbols. The original understanding of the DPR as a military government is giving way to the idea that it is a state and territory. In a number of contexts, daily and ritual, locals become residents and citizens of the DPR.

In the spring and summer of 2015 people entertained certain hopes when the newly-founded republic had partly restored the pre-war state of affairs (regular payment of wages and social benefits, certain guaranteesto smallbusinesses, and pre-war recreation and consumption practices). By now they have transformed into uncertainty about the current status and the awareness of the need to exist in several legal and economic spaces (local, Ukrainian, Russian, etc.). The self-identity of DPR residents, just as the daily experience are most often described in terms of mobility/immobility that highlight the existence of special legal statuses, the economic structure of the labor market and ways of running small businesses, and constant or "floating" migration of one or several members of a family. It is determined not so much by loyalty to the DPR as by diverse experiences unique in their entirety: firstly, the wartime routine and, secondly, the knowledge of bordercrossing rules and ways of bypassing them as well as the experience of interaction with government authorities and social networks; but in the final count, by the experience of normalizing life which essentially views the state as a debtor which is expected to repay its debts, but at the same time as a fundamentally unchangeable governing institution that makes life follow the narrow path between law and justice.

\section{References}

Assman, A., 2014. Dlinnaya ten' proshlogo. Memorialnaya kultura $i$ istoricheskaya pokitika. Translated by B. Khlebnikov. Moscow: NLO.

Kalinin, I., 2008. Dobro pozhalovat' $v$ detstvo, v kotoroye vkhod vospreshchen. Available at: http://magazines.russ.ru/nz/2008/2/ka1.html 
Kalinin, I., 2015. Gosudarstvennyi prazdnik: obryady yedinstva i ritualy razlichiy. Available at: http://magazines.russ.ru/nz/2015/2/1k.html

Malinova, O.Yu., 2012. Simvolicheskaya politika: kontury problemnogo polya. In: O. Yu. Malinova, ed. Simvolicheskaya politika, Vol. 1 Konstruirovanie predstavleniy o proshlom kak vlastny resurs. Moscow: INION RAN, pp. 5-15.

Malinova, O.Yu., 2015. Mif kak kategoria simvolicheskoi politiki. In: In: O.Yu. Malinova, ed. Simvolicheskaya politika, Vol. 3. Politicheskiye funktsii mifov. Moscow: INION RAN, pp. 5-24.

Miller, A. 2012. Politicheskiye simvoly i istoricheskaya politika. In: O. Yu. Malinova, ed. Simvolicheskaya politika, Vol. 1. Konstruirovanie predstavleniy o proshlom kak vlastny resurs. Moscow: INION RAN, pp. 164-174.

Ushkin, S.A., 2009. Smert' zhiva i stoyala na meste. In: N. A. Kypin N.A., O.A. Mikhailova, eds. Sovetskoye proshloye i kultura nastoyachshego. Yekarinburg: Urals University Press, pp. 175-190.

Humphrey, C., 2010. Post-Soviet transformations in Asian Russia: Anthropological essays.

Navaro-Yashin, Yu., 2012. The make-believe space. Affective geography in a postwar polity. Durham, NC and London: Duke University Press.

Shevchenko O., 2009. Crisis and the everyday in post-socialist Moscow. Bloomington: Indiana University Press.

Ssorin-Chaikov, N., 2003. The social life of the state in subarctic Siberia. Stanford, CA: Stanford University Press.

Oushakine, S. 2009. The patriotism of despair: Nation, war, and loss in Russia. N.Y.-London: Cornell University Press, Ithaca. 